\title{
СОЦИОЛОГИЧЕСКИЙ ЛЕКТОРИЙ
}

\author{
DOI: 10.22363/2313-2272-2018-18-3-532-541
}

\section{NATIONAL VALUES OF THE RUSSIAN EDUCATION UNDER THE INTERNATIONAL INTEGRATION*}

\author{
Shafranov-Kutsev G.F., Yarkova E.N. \\ Tyumen State University \\ Lenina St., 25, Tyumen, 625000, Russia \\ (e-mail: shafranov-kutsev@utmn.ru; yarkovaeleni@yandex.ru)
}

\begin{abstract}
One of the widely discussed challenges under the international integration of the Russian education is the preservation of national educational values. The fate of the Russian educational traditions largely depends on the attitudes of the scientific-pedagogical community towards them. The article aims to identify the position of the representatives of this social-professional group to the values of the national education, to describe their role in the processes of modernization of the Russian education. The main empirical basis of the article is the contemporary Russian scientific-educational discourse - articles and monographs considering the values of the Russian education and their role in the processes of international integration of education. The key method of the research is the qualitative content analysis of a wide range of research texts. Based on the results of the analysis of the contemporary scientific-pedagogical discourse, the authors identify three main approaches to the traditions of the national education: nihilistic, apologetic, and realistic. The authors emphasize the counter-productiveness of both unambiguously positive and unambiguously negative attitudes toward these traditions and insist on the creative potential of the realistic, i.e. critically-analytical, approach. The article affirms the significance of the versatile (multidisciplinary) education, of the fundamental, holistic, systemic, elite education, and the great importance of the unity of education together with the high value of patriotic education. The specificity of these values is revealed through correlation with their antipodes such as narrow, limited-applied, eclectic-fragmentary, mass, morally and patriotically neutral education. The authors believe that the competitive education is the one that aims at developing of creative-scientific competences rather than utilitarian-technological ones.
\end{abstract}

Key words: education; integration; unification; consolidation; values; fundamental education; morally oriented education; patriotic education

International integration of education is an objective process in the perspective of world history but it can be achieved by various strategies. Thus, the idea and aim of the so-called 'unification' or standardization is to eliminate the existing national features of education to make the national educational systems meet the uniform standards. Some Russian researchers ironically call this strategy 'Bolonization'. V.V. Mironov describes the differences in strategies for implementing Bologna agreements in Russia and Europe and stresses that the rectors of the largest universities in Germany, France, and Italy are very cautious about 'Bolonization' and insist on

* C G.F. Shafranov-Kutsev, E.N. Yarkova, 2018. 
preserving national priorities of their educational systems. However, in Russia 'Bolonization' means almost complete loss of national priorities for "implementation of the Bologna agreements aims at destroying one of the strongest educational systems in the world - the Russian education" [15. P. 5].

The idea and aim of another strategy is 'consolidation', which, on the one hand, involves formal standardization of educational institutions, and, on the other hand, preservation of their crucial national features. We can consider as an example of the consolidation strategy within the international integration of education the development of education in China, where the ideas of traditional Confucian culture serve as an ideological basis for innovative transformations [25]. Another example is the transformation of education in India, where the Vedic traditions are not uprooted but rather modified according to the contemporary situation [28].

Today the advantages of the consolidation strategy for the international integration of education, which increases the creative potential of both national and world educational systems, are more and more evident. Accordingly, one of the urgent questions for Russia are future prospects for the national education values, i.e. the future of the historically established Russian educational traditions. This problem is extremely complicated in the Russian society for it has to answer two questions. First, how to preserve and develop the best traditions, i.e. the national educational values; second, what educational traditions can be considered national values. One of the most relevant ways to answer these two questions is to address the reference group, i.e. the today's Russian academic-educational community. Although national values of the Russian education have attracted the research interest only recently, today they are defined in a large number of works. Thus, the article aims to analyze and group these values, and to identify their role in the international integration of the Russian education.

We use the analytical sociological approach that focus on certain types of value orientations of individuals to construct the corresponding causal schemes [8]. We conduct an analysis of a wide range of texts by national and foreign representatives of the academic-educational community, which highlight certain aspects of the problem under study. The key method of research is qualitative content analysis of different interpretations of the national educational values, their role in the processes of international integration and modernization of education. Such a qualitative textual analysis allows to identify both the national educational values and their role in the international integration of educational systems, while the quantitative methods in the study of value structures proved not to be sufficient.

\section{TRADITIONS OF THE RUSSIAN EDUCATION - FROM THE PAST TO THE FUTURE}

The national features of the Russian education are rather complicated and to some extent controversial. Partly this is due to the fact that the models of the university education in Russia were adopted from the European countries. The national education in general developed in the course of a catch-up modernization. First Russian universities were founded according to the models of German and French universities. However, 
the university education in Russia incorporated the features of Russian mentality and unique national identity and traditions [4]. One of the pre-Soviet traditions was to position the university as a social institution with the main function of (re)producing the national intellectual elite and not just training professionals in demand of society. The Russian intelligentsia has always been different from the Western intellectuals who are professionally engaged in intellectual activities and do not claim to be the keepers of 'the higher values'. Primarily, these values involve the responsibility for the fate of the country, empathy for the "the miserable and discriminated", the desire to resist forces that hinder the Russian national development [10].

Another typical Russian educational tradition is the culture-based approach. The notion of the 'culture-based model of education' focusing on liberal arts culture was introduced by A.A. Zapesotsky. It implies the focus on morality, religion, philosophy and creativity [30], and considers the 'culture-based education' as the education of the future. However, the university education in Russia in its broadest sense has always followed the culture-based way of development.

Since the early Soviet era the Russian education has undergone serious changes determined by its radical shift towards democracy (emergence of the working class, i.e. 'proletariat', rural youth becoming students, etc.), by the dominance of the MarxistLeninist ideology among the youth and feeling of internationalism. However, despite such radical changes, the traditions of pre-Soviet education were not completely lost but rather enriched by the new Soviet traditions stimulating extremely ambiguous attitudes to the education. Thus, even today there is a widespread estimate of the Soviet education completely denying its value. The nihilistic perception of the Soviet education as "dark ages" explains such denial by the dominance of ideology and uncritical thinking. For example, E.V. Gilbo believes that the Soviet educational system was initially designed to train skilled slaves or puppets incapable of individual actions, protection of their own interests, and fulfilling of their own projects [5]. This position can hardly be considered constructive and relevant should we take into account just one fact that "UNESCO in 1991 ranked the Soviet higher education the third in the world" [13. P. 30].

Another equally popular perception of the Soviet education considers it as an ideal educational system. From such an idealistic point of view, the Soviet education is the best in the world history of education. For example, M.V. Boguslavsky names the 1970's1980 ' the "golden age" of the Russian education and offers a model of "retroactive modernization" or the retro-innovation of education [2. P. 6]. This position is also not-balanced partly due to the significant number of distortions, periods of stagnation and ineffective campaigns in the Soviet education. The most vulnerable part of the Soviet university education was poor teaching of foreign languages at the non-linguistic faculties, lack of foreign research literature and international communication of scholars. The implications of these features of the Soviet education are still quite obvious today.

The third and most consistent position is the realistic one. Its main idea is the critical analysis of the Soviet education aimed at its deconstruction and identification of its positive and negative aspects [29]. The deconstruction allows to reveal the national education values which have to be saved and developed. 


\section{THE SYSTEM OF THE NATIONAL VALUES OF THE RUSSIAN EDUCATION}

What values of the Soviet educational legacy should be saved and developed? The results of the analysis of the wide range of texts, which are not presented in the article due to the limitations of the scientific publication, allowed us to identify the integral, interconnected, inherent system of values of the Russian education. First, it is the value of the fundamental education. Many authors insist on the necessity to save and development a broad-model education not limited to teaching/learning of the professional disciplines but including the development of the general worldview by liberal and social courses that make up a versatile education in Russia. This model is a significant factor in developing creativity for it is not a set of strictly specialized methods but a worldview. For example, K.K. Colin believes that a single-discipline specialist can only use the ready-made technologies but is unable to create something new: “...the traditional Russian system of education is much more promising here. Its revival can provide our country with significant strategic advantages over the Western countries in the era of information society and new technologies development" [11. P. 35].

Second, the fundamental and multidisciplinary education is a guarantee of competitiveness of university graduates. V.A. Prokhorov argues that "today only a well-educated person can be socially protected and capable of choosing his way and moving among different careers" [21. P. 83]. It is noteworthy that the contemporary Western philosophy and sociology of education also praise the versatile model of education. I. and D. Tarrant believe that the versatile education differs from any specialized one in its orientation to improve personality, to drastically change one's values and transform the person into a creator [26. P. 111].

Third, it is the value of integral and systemic - holistic and not fragmentary educational system, in which every discipline is presented in its integrity and completeness of information, as a part of the system and not an isolated fragment that needs to be studied and followed up. The very idea of fragmentary education is deeply rooted in the postmodern philosophy and sociology of education. The latter is known to promote a denial to generalize and conceptualize knowledge to avoid the total power of reason [19].

However, many Russian researchers consider the fragmentation of education as its negative feature. S.A. Sharonova defines fragmentary education as a paradigm that implies "more introductory rather than thorough and consistent logics of studying disciplines. It gives rise to economic, legal, environmental and other types of knowledge such as computer and driving skills instead of developing thinking, a worldview and a functional ability to find necessary information" [23]. Moreover, many authors believe that fragmentary education leads to the clip-type thinking. "A person with this type of thinking perceives the world as a kaleidoscope of pictures constantly replacing each other and loses any logical connections between phenomena and facts of reality, and the whole picture" [6. P. 71]. It is symptomatic that a significant part of researchers speaks of fragmentary education as an attribute of industrial society, whereas holistic education is considered a part of postindustrial, information society. M.I. Nadeeva notes a new paradigmatic shift: fragmentary education and the corresponding fragmentary 
thinking evolve into a synthetic, holistic vision and thinking for the information society requires strategic thinking and integrated approaches [16. P. 333]. Some foreign authors also speak of the value of the holistic education and define it as a search for ways to avoid loss of any significant aspects of human existence by covering a wide range of philosophical trends and pedagogical practiceы [24].

Fourth, it is the value of elite education. It should be noted that in the Soviet period, the best graduates of secondary schools were selected through the Olympiads in certain disciplines, and full-time and distance university schools to become students of higher education institutions. The financial status of parents did not play a significant role in this case. Unfortunately, today the most prestigious faculties in top universities of Russia admit students largely for fee. Such a practice in the nearest future will lead to the decrease in the intellectual level of the national elite.

Moreover, the massification of education inevitably leads to its degradation for "the mass student (unlike the best ones) with medium cognitive resources has comparatively limited abilities to perceive and use an ever-growing volume of information. Accordingly, the educational product is intentionally simplified, gets standard, packed in a ready-to-use form and as consumer goods of mass demand in retail networks" [20]. It is clear that the "mass student" demands the "mass teacher". In these circumstances, the value of elite education is becoming especially urgent both for the student and teaching staff. "Russia today desperately needs elite professionals so that the elite education would be developed at all levels. We need elite kindergartens, elite schools, elite vocational schools, technical colleges, universities and even elite postgraduate and doctoral courses" [18. P. 66]. Even more emotional perception of the elite education was expressed by E.K. Ashin: “....any social system especially in the post-industrial society needs a system of the elite education, preferably as open as possible. In today's circumstances a system that denies the way to the top for the gifted (or at least makes their way harder) is destined to fail" [1. P. 83].

Fifth, it is the value of the unity of education and moral guidance. Russian researchers combine these two processes for the education in Russian universities has never been a morally neutral process of transferring value-neutral scientific knowledge. The university teacher in Russia has never been a morally neutral information translator or moderator of educational games. Moral responsibility of the teacher, subordination of all teaching activities to a "code of teaching ethics and honesty" has always been the norm. "In Russia, education has always been considered as the unity of education and moral guidance understood not just as a simple assimilation of a certain system of knowledge but as a process of spiritual and moral development" [3. P. 15].

In the years of perestroika and post-perestroika, the "code of teaching ethics and honesty" lost its relevance and the term "moral guidance" was deleted from the syllabus and legislative basis of the Russian education. In many respects, this was determined by the intention to get rid of ideological basis of the Russian educational system. However, in fact, it was not so much the elimination of the Marxist-Leninist ideology from the educational process as its replacement with a different ideology. The postmodern 'anti-pedagogy' was developed by those who promote refusal from pedagogics 
and interpret education as a totalitarian process of human depersonalization aimed at 'brainwashing' as a form of terror [22].

In the early 2000 s the imbalance of education and moral guidance in the educational process was restored. The unity of learning/teaching and moral guidance was rehabilitated although there are still followers of the postmodern philosophy and sociology of education. They often define postmodern philosophy and sociology as the 'last word' in the theory and practice of education while in fact it belongs to the 'yesterday'. Many representatives of the Russian academic-educational elite consider the process of alienating teaching from moral guidance as extremely destructive. "The collapse of the national educational system must be stopped. Professional education is to be reconstructed in such a way that we get specialists competent not only in a certain field of knowledge but also in moral issues. This type of education will continue the national educational and academic traditions" [7. P. 63]. Foreign authors also emphasize the link between moral development and education. For instance, D.M. Kopkes defines the usefulness of liberal arts and aesthetic disciplines by their contribution to development of students' ethics [12].

Sixth, it is the value of patriotic education that was an important part of the educational process both in pre-Soviet and Soviet Russia. Today Russian people of liberal (or, more accurately speaking, pseudo-liberal) views treat patriotism with disrespect and often use the term 'patriot' ironically. The positive opposition of this word is 'cosmopolitan', i.e. a citizen of the world. Just half a century ago the situation was exactly opposite and the word 'cosmopolitan' served as an abuse. Thus, the complete inversion took place as a move from one extreme to the other. It is clear that this way of thinking is limited and unproductive for it underestimates the multi-dimensional identity of the person in the contemporary world and ignores the fact that identification of oneself as a part of humanity does not contradict the feeling of belonging to a certain segment of humanity - a nation, ethnos, or region.

Moreover, the idea that in the economically developed countries and especially in the USA education is axiologically neutral and there is no patriotic education is nothing but a myth. "Young Americans are brought up from an early age in a strong belief that the United States is the best country in the world ... The feeling of patriotism and pride for their country is instilled in the US citizens by parents, schools, universities and all layers of society from an early age. School history books are $90 \%$ devoted to the history of the United States while the history of other countries and regions is given by the 'whatever remains' principle" [27. P. 19-20].

In 2015, the government of the Russian Federation approved the "Strategy for the Development of Education in the Russian Federation until 2025" based on the Federal Law "Education in the Russian Federation", which ensures that moral guidance is an integral part of education interconnected with studies but also carried out as an independent activity. The Strategy defines priorities of the system of moral values developed in the course of the Russian cultural history - love to humankind, justice, honor, honesty, personal dignity, faith in the good and desire to fulfill a moral duty to oneself and motherland. Many researchers consider patriotic education as not only a way 
to overcome the fragmentation of the Russian society but also as an effective means of fighting terrorism and extremism for patriotism is an antidote for aggressive nationalism and marginalization [14].

Let us finish the article with a few major conclusions. First, the uncritical standardization of national education according to the western model in order to achieve its international integration would lead us nowhere. It seems logically inconsistent that the restructuring of the Russian education to the standards of the European or North American universities would help to increase the competitiveness of Russian universities and direct the flow of foreign students to Russia. It is clear that the intention to study in another country is always determined by the desire to learn something special, valuable, and inherent in the culture of that country. That is why it is not reasonable to eliminate the national specifics of education. Instead, it should be preserved and developed, especially the best traditions of education. We are not 'poor folks' but rather rich heirs, and our educational heritage is not the roadblocks on the way of development of education, which must be broken immediately so that we could go straightforward.

Second, our analysis proves that the most important values of the Russian education, according to the Russian academic-education community, are the values of fundamental, holistic, elite, culturally-based, morally-oriented and patriotic education. The majority of authors consider these values as most important to increase the competitiveness of Russian universities. Perhaps, these values are the extraordinary product that would provide the 'Blue Ocean' regime for the Russian universities in the world educational market. However, we believe that the traditions of the national education can serve as a basis to develop scenarios beneficial for the national educational system.

Third, it is obvious that serious problems hinder development of the national education values. One of the major challenges is the search for an optimal way to combine traditions and innovations. The complexity of this problem is determined by the fact that there cannot be any standard algorithm to solve it. Different Russian universities would find different answers to the question. Thus, the Tyumen State University has some positive experience in supporting the long-established institutions by a newly-found elite scientific-educational School for Advanced Studies, a Polytechnic School, a university gymnasium, a School for the Gifted Students, etc. The system of individual road maps introduced at the University did not reduce the importance of developing the students' worldview and fundamental disciplines but only highlighted and strengthened their importance.

\section{REFERENCES}

[1] Ashin G.K. Elitnoe obrazovanie [Elite education]. Obschestvennye Nauki i Sovremennost. 2001; 5: 82-99 (In Russ.).

[2] Boguslavsky M.V. Konservativnaja strategija modernizacii rossijskogo obrazovanija v XX nachale XXI veka [The conservative strategy of modernization of the Russian education in the 20 - early 21 century]. Problemy Sovremennogo Obrazovaniya. 2014; 1: 5-11 (In Russ.). 
[3] Chetverikova O.N. Perestrojka obrazovanija i vospitanija v Rossii skvoz prizmu geopolitiki [Reconstruction of the Russian education through the prism of geopolitics]. Vestnik Eletskogo Gosudarstvennogo Universiteta im. I.A. Bunina. Serija: Pedagogika. 2015: 3-30 (In Russ.).

[4] Egorychev A.M. Nacionalnaja tradicija zhizni i socialnoe obrazovanie v Rossii [National tradition of life and social education in Russia]. Alma Mater. 2016; 10: 20-28 (In Russ.).

[5] Gilbo E.V. O vysshem obrazovanii v SSSR i RF [On the higher education in the USSR and Russia]. http://shel-gilbo.livejournal.com/99182.html (In Russ.).

[6] Gritsenko I.A. Klipovoe myshlenie - novy etap razvitija chelovechestva [Clip thinking as a new stage in the development of humankind]. Uchenye Zapiski. 2015; 4: $71-74$ (In Russ.).

[7] Kharseeva N.V., Yanko E.V. Problemy duhovno-nravstvennogo vospitanija v sovremennoj Rossii [Problems of spiritual-moral education in contemporary Russia]. Aspectus. 2015; 2: 5965 (In Russ.).

[8] Hedstrom P., Ylikoski P. Causal mechanisms in the social sciences. Annual Review of Sociology. 2010; 36: 49-67.

[9] Karypov A. Fundamentalnoe obrazovanie kak glavnoe konkurentnoe preimuschestvo [Fundamental education as a key competitive advantage]. Pervy Ekonomichesky. 2016; 58: 56-58 (In Russ.).

[10] Khorova P.A. K voprosu o tradiciyah rossijskogo obrazovaniya [On the traditions of the Russian education]. Khorova P.A., Vishnevsky Yu.R. (Eds.) Innovacionny potencial molodezhi: globalizaciya, politika, integraciya. Ekaterinburg; 2016. Pp. 507-511 (In Russ.).

[11] Kolin K.K. Informacionnaja antropologija: pokolenie next i novaja ugroza rassloenija chelovechestva $\mathrm{v}$ informacionnom obshhestve [Information anthropology: Generation 'next', and a new risk of the stratification of humankind in information society]. Vestnik Chelyabinskoj Gosudarstvennoj Akademii Kultury i Iskusstv. 2011; 4 (28): 32-36 (In Russ.).

[12] Kopkas J. Is the casting of utilitarian as discordant with arts education philosophy justified? Journal of Thought. 2013; 5: 52-72.

[13] Maleeva A. Shkolny standart [The school standard]. Mashiny i Mekhanizmy. 2011; 9: 28—35 (In Russ.).

[14] Matveeva S.V., Filinova N.V., Matveev P.A. Patrioticheskoe vospitanie kak faktor formirovanija cennostnyh ustanovok v vysshej shkole [Patriotic education as a factor of the values formation in the higher school]. Problemy Sovremennogo Pedagogicheskogo Obrazovaniya. 2016; 51: 270-276 (In Russ.).

[15] Mironov V.V. Bolonsky process i nacionalnaja sistema obrazovanija [The Bologna process and the national system of education]. Vestnik OGU: Gumantarnye Nauki. 2005; 2: $4-8$ (In Russ.).

[16] Nadeeva M.I. Obrazovatelnye cennosti i formirovanie obschekulturnoj kompetencii studentov tehnologicheskogo universiteta [Educational values and the formation of the students' general cultural competence in the technological university]. Vestnik Kazanskogo Tekhnologicheskogo Universiteta. 2011; 22: 333-337 (In Russ.).

[17] Newcombe N.S., Ambady N., Louis Gomez J., Klahr D., Linn M., Miller K., Mix K. Psychology's role in mathematics and science education. American Psychologist. 2009; 64 (6): $538-550$.

[18] Novikov A.M. Chto takoe elitarnoe obrazovanie [What the elite education is]. Narodnoe Obrazovanie. 2004; 1: 62-66 (In Russ.).

[19] Ogurtsov A.P. Postmodernistsky obraz cheloveka i pedagogika [The postmodernist image of man and pedagogy]. Chelovek. 2001; 3-4: 18-27 (In Russ.).

[20] Patsukevich O.V. Massovizacija vysshego obrazovanija kak sledstvie globalizacii [Massivization of the higher education as a consequence of globalization]. http://elar.urfu.ru/bitstream/10995/ 32264/1/klo_2015_124.pdf (In Russ.). 
[21] Prokhorov V.A. Fundamentalnost - osnovnoj princip postroenija inzhenernogo obrazovanija [Fundamental basis as a key principle of the engineering education]. Inzhenernoe Obrazovanie. 2012; 11: 82-84 (In Russ.).

[22] Schoenebeck von H. Antipadagogik im Dialog: eine Einfiihrung in antipadagogische. Basel; 1989.

[23] Sharonova S.A. Gumanitarnaja sostavljajushhaja fragmentarnogo obrazovanija [The humanitarian component of the fragmentary education]. E.A. Zeletdinova (Ed.). Socialno-gumanitarnoe obrazovanie vysshej shkoly Rossii v XXI veke. Astrakhan; 2009. Pp. 38 - 45 (In Russ.).

[24] Mahmoudi S., Jafari E., Nasrabadi H.A., Liaghatdar M.J. Holistic education: An approach for 21 century. International Education Studies. 2012; 5 (2): 178-186.

[25] Starr D. China and the Confucian Education Model. Durham University; 2012.

[26] Tarrant I., Tarrant J. Satisfied fools: Using J.S. Mill's notion of utility to analyze the impact of vocationalism in education within a democratic society. Journal of Philosophy of Education. 2004; 38 (1): 107-120.

[27] Koncepciya patrioticheskogo vospitaniya v Rossii. Istoricheskaya pamyat i grazhdanskoe samosoznanie [Conception of the Patriotic Education in Russia. Historical Memory and Civil Self-Conscience]. Moscow; 2014 (In Russ.).

[28] Upasana K. A comparative study of traditional education \& education with special reference to India. International Journal of Research in Management \& Business Studies. 2014; 2 (5): $149-162$.

[29] Vakhitov D.R. Obrazovatelnye sistemy SSSR i Zapada: sravnitelny analiz preimuschestv $i$ nedostatkov [Educational systems of the USSR and the West: A comparative analysis of advantages and disadvantages]. Vestnik TISBI. 2015; 1: 216-235 (In Russ.).

[30] Zapesotsky A.S. Ideya kulturocentristskoj modeli obrazovaniya [The idea of culture-centered model of education]. A.S. Zapesotsky (Ed.). Kulturno-antropologicheskie osnovy obrazovatelnoj deyatelnosti: $k$ voprosu o razrabotke kulturocentristskoj modeli vysshego obrazovaniya. Saint Petersburg; 2009. Pp. 11-26 (In Russ.).

[31] Zharenova O.A., Kechil N.V., Pakhomov E.Yu. Intellektualnaja migracija rossijan. Blizhnee $i$ dalnee zarubezhie [Intellectual Migration of Russians. The Near and Far Abroad]. Moscow; 2002 (In Russ.).

DOI: $10.22363 / 2313-2272-2018-18-3-532-541$

\title{
О НАЦИОНАЛЬНЫХ ЦЕННОСТЯХ ОТЕЧЕСТВЕННОГО ОБРАЗОВАНИЯ В УСЛОВИЯХ МЕЖДУНАРОДНОЙ ИНТЕГРАЦИИ*
}

\author{
Г.Ф. Шафранов-Куцев, Е.Н. Яркова \\ Тюменский государственный университет \\ Ул. Ленина, 25, Тюмень, 625000, Россия \\ (e-mail: shafranov-kutsev@utmn.ru; yarkovaeleni@yandex.ru)
}

Одной из широко обсуждаемых проблем в процессе международной интеграции отечественного образования является сохранение национальных ценностей образования. Судьба российских образовательных традиций во многом зависит от отношения к ним научно-педагогического

* (С Шафранов-Куцев Г.Ф., Яркова Е.Н., 2018. 
сообщества. Цель статьи - обозначить позицию представителей данной социально-профессиональной группы относительно ценностей отечественного образования, определить их роль в процессах модернизации отечественного образования. В качестве основного эмпирического материала статьи выступает современный отечественный научно-образовательный дискурс - статьи и монографии, посвященные исследованию ценностей отечественного образования, а также их роли в процессах международной интеграции образования. Ключевой метод исследования — качественный контентанализ широкого массива научно-исследовательских текстов. По итогам анализа современного научно-педагогического дискурса выделено три основных подхода к традициям отечественного образования: нигилистический, апологетический и реалистический. Авторы подчеркивают контрпродуктивность как однозначно позитивного, так и однозначно негативного отношения к этим традициям и отмечают креативный потенциал реалистического - критико-аналитического - подхода. Авторы утверждают ценность разностороннего (многопрофильного) образования, фундаментального, целостно-системного, элитарного образования, ценность единства образования и воспитания и ценность патриотически ориентированного образования. Специфика названных ценностей раскрывается через соотнесение с их антиподами: узкопрофильным, ограниченно-прикладным, эклектично-фрагментарным, массовым, нравственно и патриотически нейтральным образованием. Конкурентоспособным утверждается образование, ориентированное на получение не утилитарнотехнологических, а креативно-научных компетенций.

Ключевые слова: образование; интеграция; унификация; консолидация; ценности; фундаментальное образование; нравственно-ориентированное образование; патриотическое воспитание 